\title{
SIGN ANALYSIS OF THE INSTAGRAM USER USING SEMIOTIC CHARLES S. PEIRCE
}

\author{
Farhan Muhammad Ramadhan ${ }^{1}$, Shavira Nisa Delardhi², Ula Nisa El Fauziah ${ }^{3}$ \\ ${ }^{1}$ IKIP Siliwangi \\ ${ }^{2}$ IKIP Siliwangi \\ ${ }^{3}$ IKIP Siliwangi \\ ${ }^{1}$ barchenfarhan@gmail.com , ${ }^{2}$ shaviranisa539@gmail.com , ${ }^{3}$ ula_nisa@ymail.com
}

\begin{abstract}
Sign intentionally produced in order to signify where these signs always originate from a sender. They are formed consciously by someone, based on specific conventions, and with the aim of communicating something to someone. Nowedays, many of the signs used in social media, especially in social media Instagram as one of the popular social media that is not only used for communication but also sometime be a place to share a moment using picture or video. The objective of this research is to find out the intent of sign in the picture that user Instagram share and also analyzed picture to find out the connotation. This research uses descriptive qualitative approach such the researchers analyses the visual signifier and concept of meanings as signified the data with analyzed based on C.Peirce's triadic model of sign which consist of representament, object and interpretant. Researchers use 8 pictures random taken from Instagram user. The result of this research is the researchers find 4 words from the text in the pictures that including to energetic interpretant with the dynamical interpretant process, and also find 4 words from the text in the pictures that including to emotional interpretant with the dynamical interpretant process.
\end{abstract}

Keywords: Semiotic, Triadic Model Of Sign, Instagram

\section{INTRODUCTION}

Along with the times in science and technology, human is developed the way to communicate one to each other, the creation of various tools to help humans to facilitate their work, also influence the human desire to get more and faster information. tools to communicate one another continue to be developed to date. smartphones take a huge role in the development of science and technology. all kinds of information can be more easy delivered through this device with many type application. with the progress of this telecommunication tool all kinds of information within and outside the state can be obtained with a relatively fast time. The development of smartphones encourages some people to create social media, where they can share information one and the other. In a larger view, social media discusses the kinds of conversations that occur between an individual or a community for sharing competitiveness (Zeng, Chen, Lusch, \& Li, 2010)

In recent years, social media have experienced tremendous growth in their user base. For example, eight hundred billion users belonging to the Instagram before 2018. (CNBC, 2017). Instagram is a mobile social network that allows users share photos or video for save the moment or interact with they friend. In addition the moment can be easier shared by users Instagram. The type moment shared by the user Instagram can display photos or video users or utterances as a medium to convey messages and intentions of its users. Related to the above photo and videos share by a user similar to the sign in the sphere of semiotics study. So, it's 
called because the intention to be revealed is not expressed straightly. The utterances contained inside picture in Instagram application. This research investigates speech who had denotation and connotation in picture. Charles S. Peirce semiotic model of signification is used by researchers in studying the meaning of connotation of the connotations of speeches contained in picture shared in Instagram.

Therefore, the author will examine the utterances contained in the picture shared in Instagram application and identify the meaning contained in the utterances by using Charles S. Peirce semiotic analysis.

\section{Semiotic}

This paper contains with semiotic, applied to communications, to look at Instagram application picture and videos are share by user to use semiotics to decipher intended meanings. picture is visual and semiotic will show signs function. According to the book, The basics semiotics Definition of semiotics as a study of signs. Some experts have their own opinions on the definition of semiotics. Eco (Chandler, 2007) states that semiotics is anxious with everything wich can be taken as a sign.

Then Saussure defines semiology as a science that examines the life of signs in social life. Saussure states it in his book (Chandler, 2007), contains the statement that:
It is . . possible to conceive of a science which studies the role of signs as part of social life. It would form part of social psychology, and hence of general psychology. We shall call it. semiology (from the Greek se- meîon, 'sign'). It would investigate the nature of signs and the laws governing them. Since it does not yet exist, one cannot say for certain that it will exist. But it has a right to exist, a place ready for it in advance. Linguistics is only one branch of this general science..

Saussure also imagined semiology (semiotics) as a science of signs in general, not only linguistic signs (words). One of learns semiotics is learn the language. Saussure view semiotics as a key to unlocking a variety of cultural phenomena all of which are various sign systems.(Riley, 2001) said semiosis is part of the semiology used in semiotics to establish and determine the production and interpretation of signs. While Barthes stated semiology 'aims to take every system of signs of whatever substance and boundaries; pictures, gestures, music sounds, objects. (Kurniawan, 2001).

Although, Saussure said semiology as a general science of signs of which linguistics would form only one part, while the Roland barther argues that semiology is branch from linguistic (Riley, 2001). Saussure said that semiotics is part of dichotomies as inseverparable lateral as opposition as the signifier, significant, semaion and signified, signifie, semainomenon, speaking (parole) and the common language (langue), the syntagmatic and the paradigmatic, and also the diachronic and the synchronic.

Saussure stressed that sound and thought (or the signifier and the signified) were as inseparable as both sides of a piece of paper (Chandler, 2007)

"Just as it is impossible to take a pair of scissors and cut one side of paper without at the same time cutting the other, so it is impossible in a language to separate sound from thought or thought from sound. To separate the two for the theoretical purposes takes us into either pure psychology or pure phonetics, not linguistics". 




It is clearly can said the signification or the relative among signifier and signified, which in the quotation called by the sound and the thought, could not be separate. It supports each other. There is no sound without thought and also otherwise there is no thought without sound. the analogy of the signified (mental concept) and the signifier (material aspect) is inseparable therefore Saussure preaches with the following diagram;

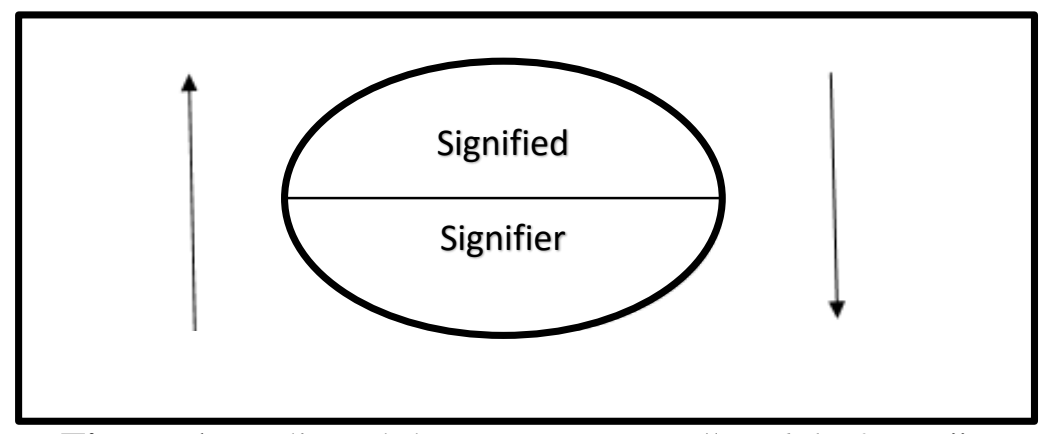

Figure.1 Ferdinand de saurse concept "model of sign"

\section{Semiotic Charles S. Peirce}

One of the American philosopher Charles Sanders Peirce which more innovation and multidimensional. He one of the most popularity was because of the theory of sign. In semiotic, Peirce said that generally the signs had substituted something for someone. According to (Sobur, 2003)Peirce argues that a sign "is something which stands to somebody for something in some respect or capacity. It is showing that somebody, creates in their mind a correspondent sign, or perhaps a additional developed a sign.

In semiotic Peirce was formulated his own model of the sign and the triadic taxonomies of signs they are:1.The Re-presentment: the form which the sign takes. 2. An Interpretant: not an interpreter but moderately the sense made of the sign.3. An Object: in which way the sign refers

A sign, or representamen, is something which stands to somebody for something in some respect or capacity. In addressing a person the sign creates the interpretation in his mind with an equivalent position or even more advanced. The created mark can specify the interpreter in the first sign. The sign stands for something, it object. In orientation to a sort of idea, which sometimes called the part of the representamen.

In other hand the sign, in a broader sense, consists of three interconnected elements three to use Peirce terminology. (1) the sign in the narrow sense, also referred to as the re-presentment, that which represents something else; (2) the object, that which the sign stands for, that which is represented by it; a finally (3) the (possible or potential) meaning the sign allows for, which may materialize as its translation into a new sign. Peirce refers to this as the interpretant.

In the semiotic the point of view between precians and the sausure view about sign are different where that semioticians make a distinction between a sign and a 'sign vehicle' (the latter being a 'signifier' to Saussureans and a 'representamen' to Peirceans)

In Peirce terms they are the relationship between representamen and its object or its interpreter, but for the purpose of continuity continue to use Saussurean and marked term markers (Chandler, 2007) Here then are the three modes: 
(1)Symbol/symbolic: where a sign didn't like a sign but which fundamentally purely conditional so need to be learned more: e.g. language in general (plus specific languages, alphabetical letters, punctuation marks, words, phrases and sentences), numbers, code, traffic lights, national flags.(2)Icon/iconic: a mode in which the signifier is perceived as resembling or imitating the signified (recognizably looking, sounding, feeling, tasting or smelling like it) being similar in possessing some of its qualities: e.g. a portrait, a cartoon. (3) Index/indexical: a mode in which the signifier is not arbitrary but is directly connected in some way (physically or causally) to the signified (regardless of intention) - this link can be observed or inferred: e.g. 'natural signs' (smoke, thunder, footprints, echoes, non-synthetic odours and flavours), medical symptoms (pain, a rash, pulse-rate), measuring.

\section{Representamen}

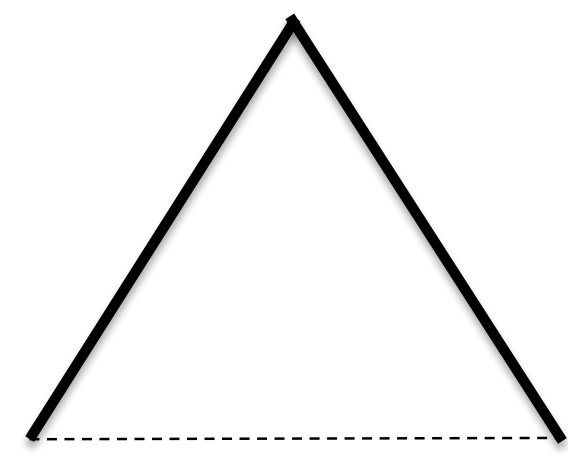

Object

Intrepretant

Figure.2 The process of Linguistic sign of Peirce

the sign of the pierce are triadic model wherre didn't have any structural sign (Hoed, 2002). the base of theory said the pierce theory are resprenantive, pierce explain his model as a simply A sign is something which stands to somebody for something in some respect or capacity. Something that say pierce call the interpretant is based to the something object. Therefore, Peirce said one of sign or represetatemen had relation triadic. Variants of Peirce's triad are often presented as 'the semiotictriangle. From this procces produce a cycle coninously. the interpretant will be representatemnt and the respretatemnt will be intre pretant. this statment same that argues fom Umbreto whre thenname of this cycle unlimited semiotics. Peirce argues that pragmatism can ensure its meaning is complete explanatory studies, or 'significant effects' of signs, he proceeded to elaborate a trichotomy of emotional, energetic, and logical interpretation. piece explains interpretations in particular: immediate, dynamic, and final interpreters. respectively, the total un-analyzed effect generated by the first sign, the actual through effect on the translator, and finally, the 'effect to be generated are two irreducible trichotomies. Marks on any mind where circumstances should enable it to work out its full effect Pierces later classification of the "interpretant" may thus be presented as follows: 


\begin{tabular}{|c|c|c|c|}
\hline Emotional Interpretant & $\begin{array}{c}\text { Immediate Interpretant } \\
\text { an emotion }\end{array}$ & Dynamical Interpretant & Final Interpretant \\
\hline Energetic Interpretant & $\begin{array}{c}\text { idea of an effort, } \\
\text { experience, or action }\end{array}$ & Action & \\
\hline Logical Interpretant & $\begin{array}{c}\text { idea of a general form, } \\
\text { meaning, or habit }\end{array}$ & Habit & $\begin{array}{c}\text { intended habit, general } \\
\text { form of a habit }\end{array}$ \\
\hline
\end{tabular}

Table.1 Peircce trichotomies interpretant

Its clearer from the concept of "significate effect," the basic idea of Peirce's pragmatism consists in that a sign's meaning cannot be divided from its effects. But a distinction has to be made between three classes of effects: the concrete significate effect as a Second, that is singular emotions, actions, or habits, as they are summarized by the concept of "dynamical interpretant;" the qualitative possibility of such effects; and the general significate effect as a Third, that is the final-logical interpretant.

\section{METHOD}

This research analysis sign of the picture Instagram user using Semiotic Charles S. Peirce. This study uses descriptive qualitative approach since the writer analyses the visual picture as signifiers and the concept of meanings as signified as the data. The analysis is included to document analysis because the data are taken from the picture was share by Instagram user.

\section{RESULTS AND DISCUSSION}

\section{Results}

There is an 8 picture form Instagram what the analysis by the researchers. The analysis using pierce theory for analyze the meaning and the process of semiotic in the text or picture that user Instagram share.

1. Picture 1



Picture. 1 Data analysis sign number 1 


\section{Oh, so you wanna argue? Bring it I got my caps lock on}

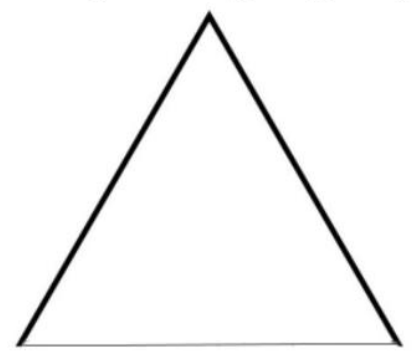

CapsLock

Symbol of anger

Figure.3 Analysis from picture 1

Explanation: The representament form the picture are the sentence "oh, so you wanna argue? bring it I got my caps lock on "the object of the picture is the word "caps lock ". The Caps lock it is a part of keyboard button that you press to make any letters you type appear as capital letters until you press it again (Simpson, 1989). The caps lock in the pierce model triagic caps lock as representament. from the statement "Oh, so you wanna argue? Bring it I got my caps lock on "as the intrpretant, and the object is the angry because when someone use the caps lock on its mean the button on a keyboard button that makes the letters typed capital letters after the pressing. The capital leters showing a word stress and the effect of angriness.

\section{Picture 2}

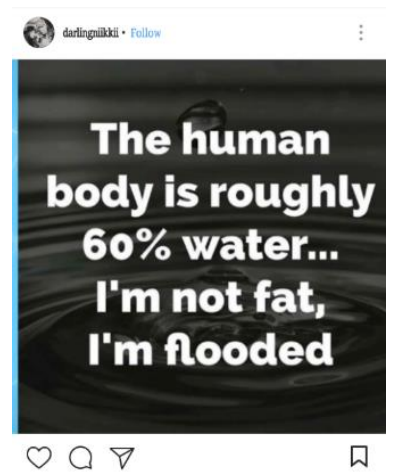

Picture.2 Data analysis sign number 2

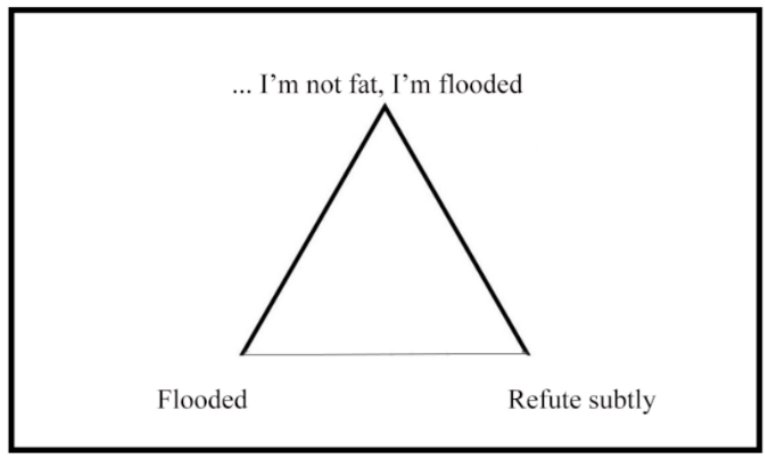

Figure.4 Analysis from picture 2 
Explanation: Stand of the picture "The human body is roughly $60 \%$ water ... I'm not fat, I'm flooded" the word "I'm nor fat, I'm flooded" stand as the representament. And the object the word "flooded" from the representament. The picture what the user Instagram share have an interpretant "refute subtly" its mean that the sentence of representatment only for joke and for made fun, because the sentence showing the funniest.

\section{Picture 3}

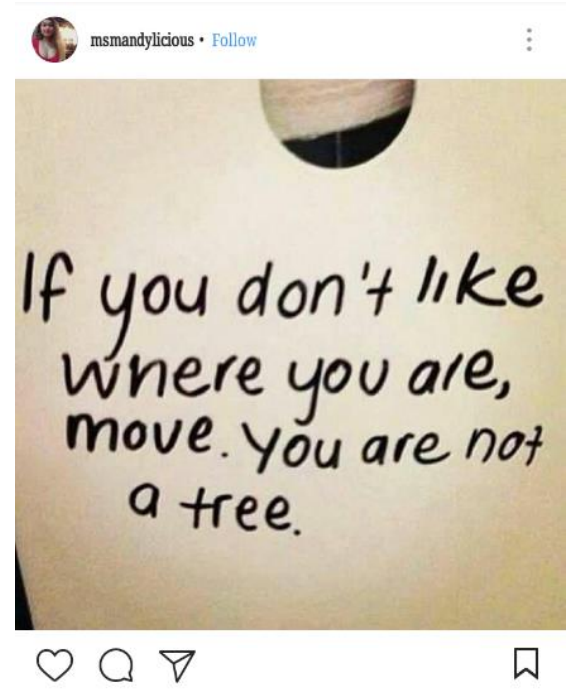

Picture.3 Data analysis sign number 3

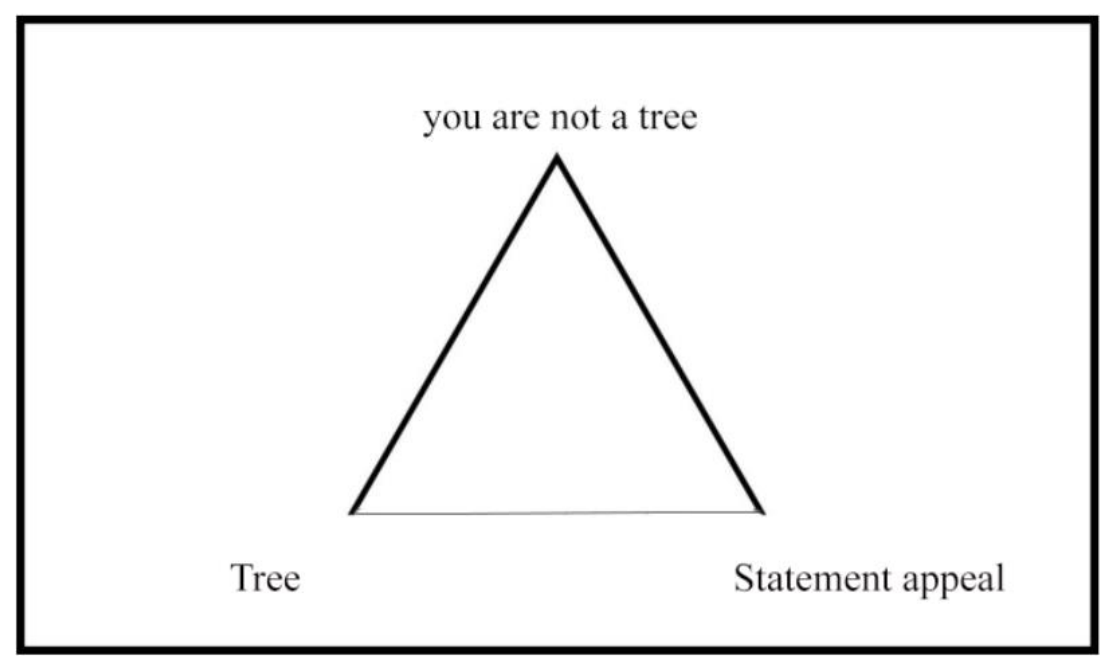

Figure. 5 Analysis from picture 3

Explanation: The word "you are not a tree" can represent the representament from the picture. And the object the word" tree" from the representament. The picture what the user Instagram share have an interpretant "statement appeal" because it has the different a meaning from object before to the interpretant, the word "tree" Tree it's a tall plant with a wooden trunk and branch (Simpson, 1989). But the interpretant message that will share is the statement appeal because the word moves and the tree just an allusion to move from unpleasant circumstances, because humans can determine where and how their condition and not just surrender. 
4. picture 4

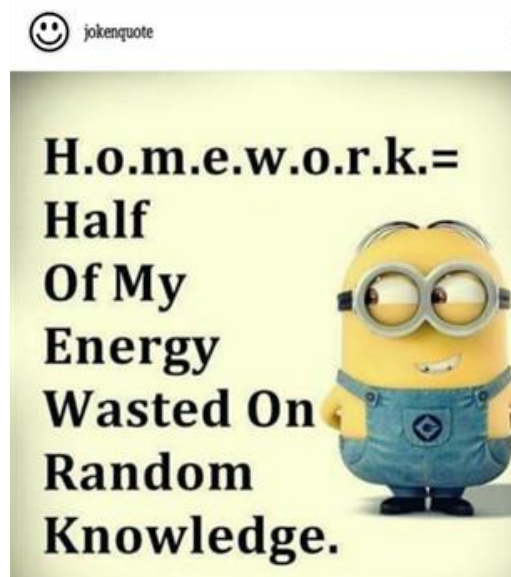

$\odot \bigcirc \nabla$ の

Picture.4 Data analysis sign number 4

Half of my energy wasted on random knowledge

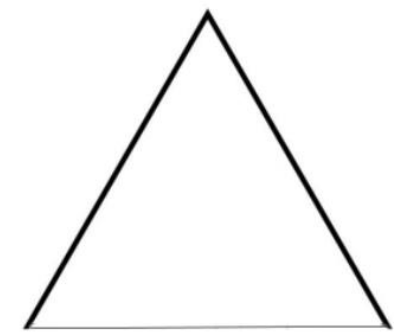

Home Work

Disillusionment

Figure.6 Analysis from picture 4

Explanation: The word "half of my energy wasted on random knowledge" play as word representament $\mathrm{t}$ from the picture. and the object of the picture are the "home work", the home work have the interpretant meaning Homework is Schoolwork that a pupil is required to do at home.(Simpson, 1989) But in this case the picture above the intrepretant meaning of the user Instagram share is the disillusionment, the disillusionment as the interpretant its showing the student disillusionment with the teacher's assigned task is a waste the energy to something that unimportant. 
5. Picture 5

3 am phone

call.."hey are

you asleep??"

...."No l'm

Skydiving"..

$\circ \bigcirc \nabla$

ロ

Picture.5 Data analysis sign number 5

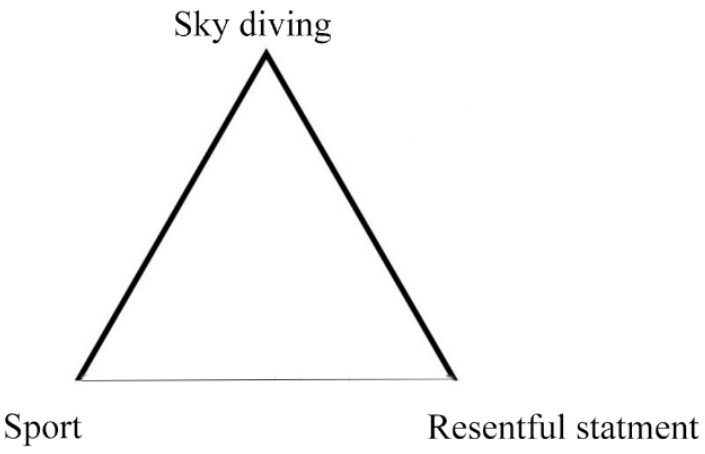

Figure.7 Analysis from picture 5

Explanation: The word "sky diving" be word representament from the picture above. The object is the sport. The meaning of sky diving is sport in wich you jump from plane and fall for as long as safely can before opening your pharachute (Simpson, 1989). In this case the picture above the interpretant meaning or the interpretation of the user Instagram share is the resentful statement. Because the full of statement in picture above is show something that should not be asked because it is clear early morning is the time to sleep and rest. 
6. picture no 6

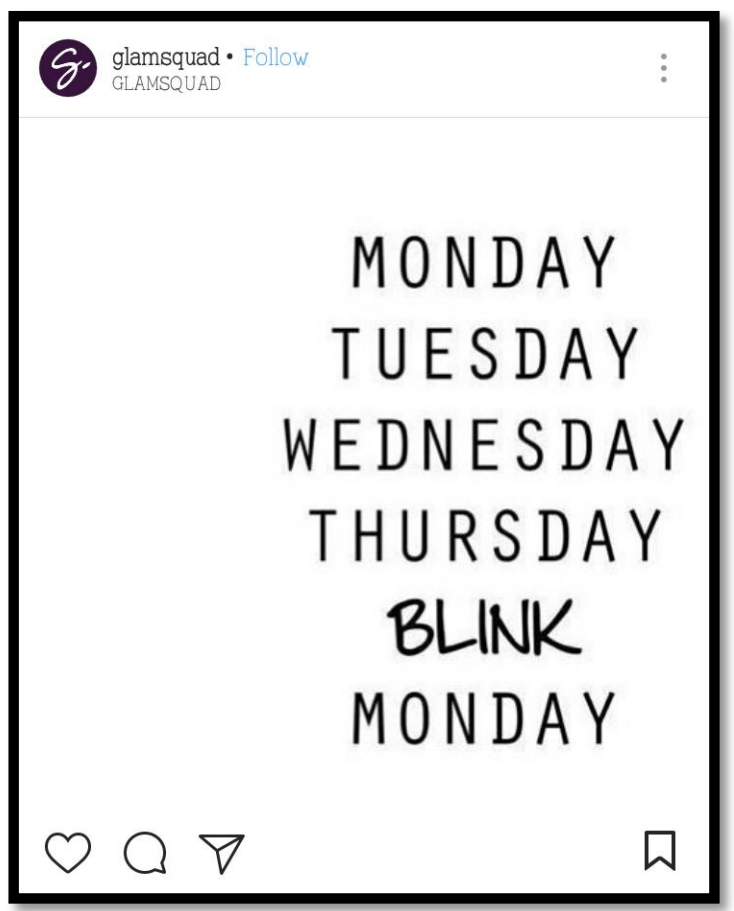

Picture.6 Data analysis sign number 6

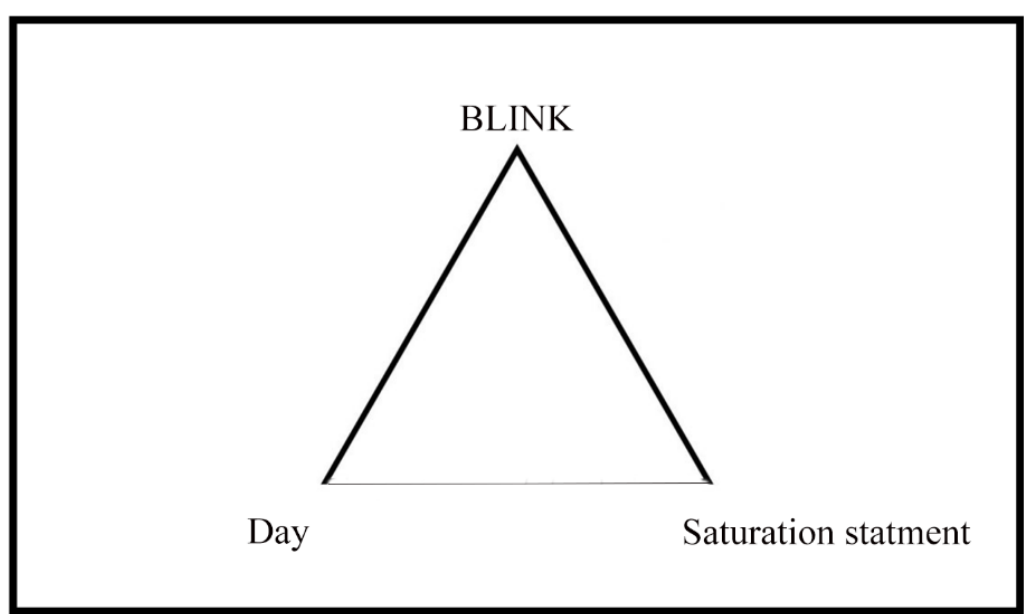

Figure.8 Analysis from picture 6

Explanation: The word "Blink" be word $\mathrm{r}$ representament from the picture above. The object is the "day". In the picture above the word Sunday are change to be a word blink. Its showing the saturation statement as the intepretant. The user Instagram share that picture to showing their statement of the saturation, where is the day of the week are full for work. And they think there is day for a holiday or take arrest in one day of the week because very busy to work. 
7.Picture 7

\section{don't give up \\ on your \\ dreams.}

\section{keep}

sleeping.

$\bigcirc \bigcirc \nabla$

ロ

Picture.7 Data analysis sign number 7

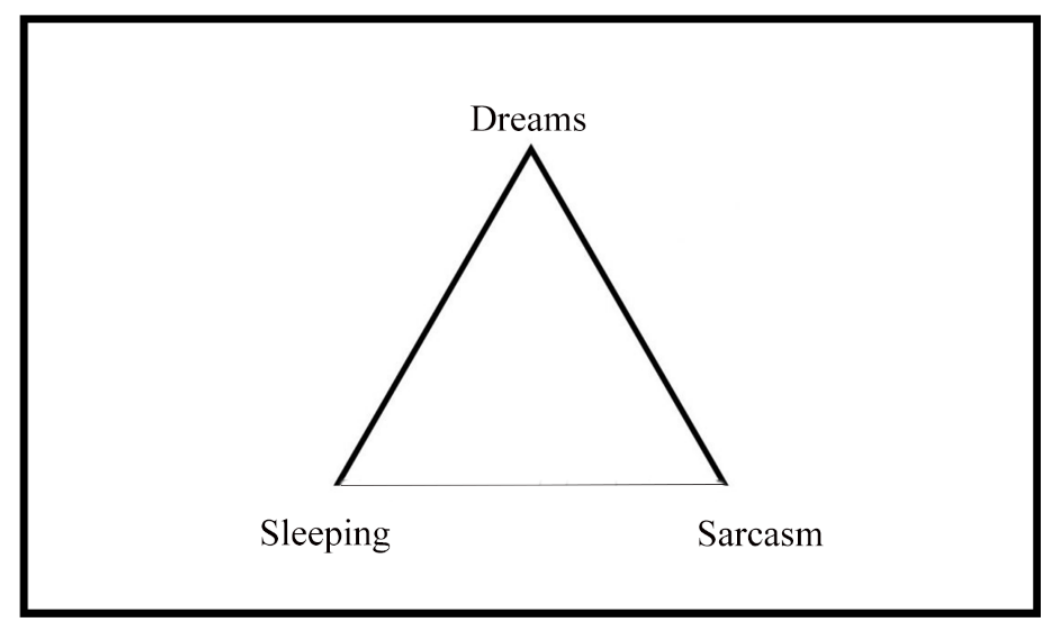

Figure.9 Analysis from picture 7

Explanation: word representatment are the word of "dreams" from the picture above. The object is the "sleeping". In this case the sleeping is be the object. Sleeping its one a process where are the human can dream (Simpson, 1989). The words dreams have another meaning it's like the dream in sleeping are also have the dream of goal. In the picture above the interpretant meaning or the interpretation of the user Instagram share is the "sarcasm". Where is if someone cannot catch a dream or goal they should keep sleeping not do what they want to reach a goal. 
8.Picture 8

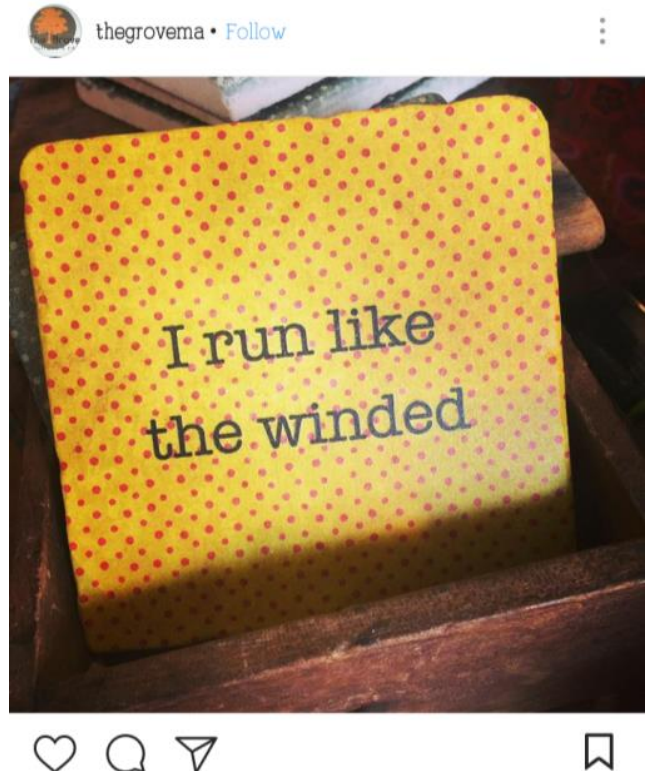

Picture.8 Data analysis sign number 8

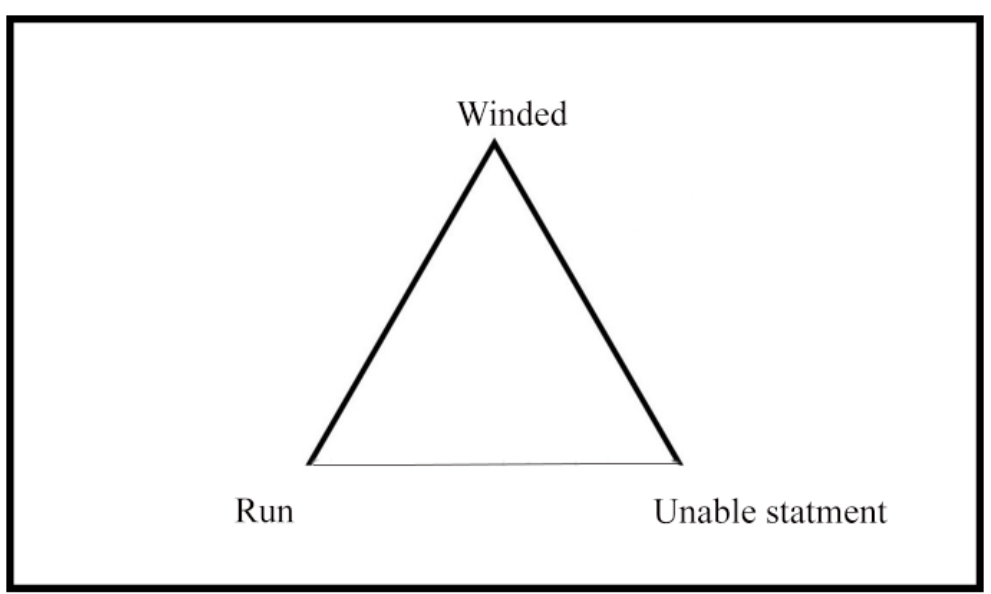

Figure.10 Analysis from picture 8

Explanation: the word representatment from the picture above it is "Winded". The object is the "Run". In the picture above the run be the object from representatment. And the interpretant is unable statement. The picture is showing the unable statement from someone and its showing the difficult of someone to do something. In the picture the difficult are described by run like winded.

\section{CONCLUSION}

In this analysis sign of the picture Instagram user using Semiotic Charles S. Peirce. There are 8 Instagram pictures are share in this study which are analyzed to know the connotation. Speech connotations are taken from denotations that are categorized as inanimate objects. The utterances and their connotations are as follows :

1. The representament are the sentence "Oh, so you wanna argue? bring it I got my caps lock on". The object from this statement are the word "Caps Lock ". And for the interpretant 


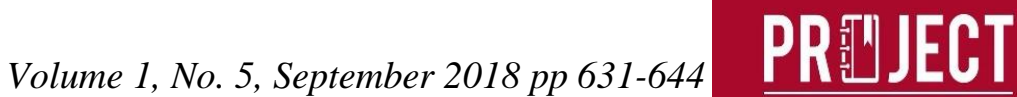

meaning is the symbol of anger, where is the emotional interpretant with the process dynamical interpretant as a sign .

2. The representament are the sentence "I'm nor fat, I'm flooded". The object from this statement are the word "Flooded". And for the interpretant meaning is refute subtly. Where is the interpretant include on part of the energetic interpretant with the process dynamical interpretant

3. The representament are the sentence "You are not tree". The object from this statement are the word "Tree". And for the interpretant meaning is statement appeal. Where is the interpretant is a part of the energetic interpretant with the process dynamical interpretant

4. The representament are the sentence "half of my energy wasted on random knowledge". The object from this statement are "Home work". And for the interpretant meaning is disillusionment. Where is the interpretant is a sign on part of the emotional interpretant with the process dynamical interpretant.

5. The representament are the sentence "Sky diving". The object from this statement are the "Sport". And for the interpretant meaning is resentful statement part of the emotional interpretant with the process dynamical interpretant

6. The representament are the sentence "Blink". The object from this statement is "Day". And for the interpretant meaning is saturation stamen. Where is the interpretant is part of the emotional interpretant with the process dynamical interpretant

7. The representament are the sentence "Dreams". The object from this statement "Sleeping". And for the interpretant meaning is sarcasm. Where is the interpretant include on the part of the energetic interpretant with the process dynamical interpretant

8. The representament are the word "Winded". The object from this statement is "Run". And for the interpretant meaning is unable statement. Where is the interpretant is part of the energetic interpretant with the process dynamical interpretant

In social media the people had a freedom to express what they feel, sometimes the user also give some messages un they picture what they shared to make sure the viewers to carry out what happened. This picture built by using semiotic pragmatism of pierce that analyzed in semiosis word by word that showing an object. The picture where shared by the user interpretation in pierce theory. This is a process by showing the symbol or some word in a picture. The picture as the object of sign of the user perspective that showing in these picture that in pierce theory is called legisign. Based on the research the reasearcher find 4 interpretant with the energetic interpretant with process dynamical interpretant, the researcher also find 4 emotional interpretant with dynamical interpretant.

The intrepretant that made by using perspective and approach of the user can easy to share to other, some people maybe think the picture its only joke or some quote without the purpose with the meaning of the picture who shared. The signs in the picture are hold the important role as a successive the expression some user to send the message one to each other in Instagram by using the triadic theory of pierce. And icon, text, symbol is build description it be a good analysis.

\section{REFERENCES}

Chandler, D. (2007). Semiotics the Basics, Second Edition - 69249454-chandler-semiotics.pdf, 
29-30. https://doi.org/10.1016/S0378-2166(02)00176-5

Hoed, B. (2002). Strukturalisme, Pragmatik dan Semiotik dalam Kajian Budaya in Indonesia: Tanda yang Retak. Jakarta: Wedatama Widya Sastra.

Kurniawan. (2001). Semiologi Roland barthes. Magelang: Indonesia Tera.

Riley, K. (2001). Routledge Dictionary of Language and Linguistics. Journal of English Linguistics (Vol. 29). https://doi.org/10.1177/00754240122005387

Saussure, F. de. (1959). General principles: Nature of the linguistic sign. Course in General Linguistics, 9(6), 64-70.

Simpson, J. \& W. (1989). Oxford Phrasal Verbs Dictionary for Learners of English. Retrieved from http://discovery.ucl.ac.uk/22964/

Sobur, A. (2003). Semiotika Komunikasi. Bandung: Remaja Rosdakarya.

Zeng, D., Chen, H., Lusch, R., \& Li, S. H. (2010). Social media analytics and intelligence. IEEE Intelligent Systems, 25(6), 13-16. https://doi.org/10.1109/MIS.2010.151 